\title{
Management of Petroleum Impacted Soil with Phytoremediation and Soil Amendments in Ekpan Delta State, Nigeria
}

\author{
Sunday Ighovie Efe, Aboh Edwin Okpali \\ Department of Geography and Regional Planning, Delta State University, Abraka, Nigeria. \\ Email: efesunday@yahoo.com, greenstarp@yahoo.co.uk
}

Received August 23 ${ }^{\text {rd }}, 2011$; revised February $7^{\text {th }}$, 2012; accepted March $15^{\text {th }}, 2012$

\begin{abstract}
The study is aimed at evaluating the effectiveness of phytoremediation in the management of oil impacted soil in Ekpan communities of Delta state, Nigeria. To do this, the study adopted an experimental research design that involve the use of phytoremediation (carpet grass Axonopus compressus) and nutsedge Cyperus rotundus) in the management of petroleum impacted soil site in Ekpan. This experiment spans for three months periods (one planting season). It involves the treatment of the oil impacted site with different plant species and soil amendments. Laboratory analysis of the soil samples was conducted to determine the effect of phytoremediation and soil amendments on hydrocarbon loss in oil impacted sites. The study revealed that the combined effect of Axonopus sp., Cyperus sp. and oil amendments accounted for 59\% reduction in hydrocarbon. However Axonopus sp. and Cyperus sp. accounted for $47 \%$ and $48 \%$ reduction in hydrocarbon respectively. This shows that though, both plant species can be used successfully as a phytoremediation technique for the reclamation of oil impacted soils, but Axonopus sp. and Cyperus sp. was the most effective when applied with soil amendment (organic and inorganic manure). It is therefore recommended that iindigenous plant species (particularly Axonopus sp. and Cyperus sp.) should be used together with soil amendments in phytoremediation rather than the traditional bioremediation involving the use of microorganism. Oil companies operating in the Niger Delta region of Nigeria are encouraged not only to carry out physical clean-up of oil spills but should also carry out bioremediation to restore the environment back to its natural or near natural state. The methodology adopted in this study could be followed by oil companies to manage oil impacted soils in the Niger-Delta environment in Nigeria and indeed everywhere in the world.
\end{abstract}

Keywords: Phytoremediation; Oil Impacted; Soil; Amendments; Ekpan

\section{Introduction}

The problem of environmental pollution has assumed an unprecedented proportion in many parts of the world [1,2], especially in Nigeria and the Niger-Delta region in particular. The Niger-Delta region of Nigeria is characterized by petroleum exploration, exploitation and production activities and hence, daily predisposed to oil pollution of varying magnitudes. The land, water bodies and marshes have become heavily polluted due to accumulation from several years of incipient and perceived pollution of the ecosystem. It is believed according to UN report, that an average riverine dweller of the Niger Delta is exposed to polluted air, polluted water and polluted food, hence facing health hazard resulting to reduced life expectancy [3]. The problem of severe environmental degradation and devastation as a result of oil exploration and exploitation in the Niger-Delta has been very glaring. Reference [4] stated that oil exploration and exploitation have over the last four decades impacted disastrously on the socio-physical environment of the Niger-Delta oil bearing communities, massively threatening the subsistent peasant economy and the environment and hence, the entire livelihood and basic survival of the people. Also this region is bedeviled with this problem perhaps owing to interplay of demographic and socio-economic forces coupled with the various activities that revolve round the exploration for and exploitation of large deposit of crude oil discovered in this region [5].

Prior to the establishment of Warri Refinery and Petrochemical Company (WRPC) and Pipelines and Products Marketing Company (PPMC) in Ekpan, the adjoining lands of Ekpan were green and forested. Fishing was a lucrative venture and farming rewarding. Today, the story is different. The oil impacted land in Ekpan due to pollution from the oil facilities, mostly caused by sabo- 
teurs who vandalize oil pipelines, has been rendered unproductive and water bodies polluted. Although physical clean-up is usually carried out by these companies if any spill does occur, but the lands are left bare, without adequate replanting to restore the environment to its natural or near-natural state [6], this constitutes a major problem as more expanse of land is lost yearly to environmental degradation. The local dwellers in the region in particular are sure to experiencing more acute environmental degradation and devastation in the nearest future, if nothing is done to remedy the already devastated, fragile, and delicate ecosystem. This explains why there is urgent need to employ an efficient, easily managed, cost effective and environmentally friendly technology for the management of oil contaminated soil in Ekpan.

Oil impacted soils have been successfully managed in some parts of the world using various plant species, and this was demonstrated by [7] who opined that plants could be used to remove contaminants from the soil and/ groundwater. Remediation of petroleum contaminated soil can be carried out by different methods including physico-chemical and biological approaches, phytoremediation and bioremediation. Compared to physico-chemical methods, bioremediation is thought to be low cost, low environmental risk but longer time needed. And phytoremediation is thought to be low cost, low environmental risk faster and require shorter time needed [8]. A variety of bioremediation methods have been developed to increase the degradation rate of petroleum in soil. Isolation of effective microorganisms has been well studied before and proved to be effective method in bioremediation of petroleum polluted soil $[9,10]$. For example, $B$. subtilis was proved to be a better hydrocarbon degrader than the other isolates, and the rates of degradation of diesel oil by the isolate at the end of day one, day twelve and day twenty-seven were $5.8 \times 10^{-4}, 1.83 \times 10^{-3}$ and $1.05 \times 10^{-3} \mathrm{~g} / \mathrm{h}$, respectively. In another study, strains were isolated from petroleum polluted soil and identified as Pseudomonas pseudoalcaligenes, Bacillus firmus, Bacillus alvei, Penicillium funiculosum, Aspergillus sydowii and Rhizopus sp., and they removed 79\%, 80\%, 68\%, $86 \%, 81 \%$ and $67 \%$ of TPH [1]. Genus Stenotrophomonas, Bacillus, Brevibacillus, Nocardiodes and Pseudomonas were used in combination and give a degradation rate of $67 \%$ after only 12 days of treatment [11]. It has been proved that the effectiveness of the mixed consortium was significantly superior to that obtained by individual strains [12] and [13].

However according to [14] phytoremediation studies has shown that several types of petroleum products and solvents, are degraded faster in the presence of plants in which transpiration of water, oxygen transport, biological stimulation in the root zone and plant uptake of chemi- cals are thought to be influencing factors [8]. Microbial numbers in the vegetated soil were significantly higher than the unvegetated soils in the rhizosphere $[11,15,16]$. The following species of plants are general used: Sorghum bicolor, Linum usitatissumum [17], Pannicum, Eleusine indica (L.) Gaerth, Tall Fescue [15] and Phaseolus coccineus [18]. In a plant screening process, ryegrass, sorghum, maize, alfalfa, Bermuda grass, rice, kudzu and beggar ticks were proved to be more effective in degrading petroleum hydrocarbon [19], especially ryegrass is superior in enhancing hydrocarbon degradation [20]. Compared to other remediation approaches,

From the foregoing, it is clear that currently, phytoremediation is used for treating many classes of contaminants, including petroleum hydrocarbon, pesticides, explosives, heavy metals as well as Chlorinated Volatile Organic Compounds-CVOC [19,21,22]. Though these methods and processes of preventing, removing and or correcting the negative effects of oil pollutants released into the soil exist but their application in this region has either been poorly implemented or not at all, a situation that is worsening owing probably to claims of lack of virile regulatory bodies and overwhelming dependence of government on crude oil for income. Also, despite these findings oil companies' operating in the region and Nigeria government has glossed over it, probably because of lack of awareness and application in this environment. In fact to them, this management practice has not been tested in most part of Niger Delta especially Ekpan of Delta State. Based on this problem and neglect, this study is set to assess the effectiveness of phytoremediation in the management of oil impacted soil in Ekpan of Delta state, Nigeria.

\section{Methods of Data Collection}

The study adopted an experimental research design that involves the use of phytoremediation in the management of petroleum impacted soil in Ekpan. This experiment spans for three months periods (one planting season). It involves treatment of the site with different plant species and soil amendments. Laboratory analysis of the soil samples was conducted to determine the effect of phytoremediation and soil amendments on hydrocarbon loss in oil impacted sites. The experimental plots were subdivided into eight blocks based on the number of treatment for the study. A total of sixteen soil samples were collected for laboratory analysis. One soil samples was collected from each block at the beginning of the experiment and same samples were collected at the end of the experiment for laboratory analysis of TOG, expressed in milligram per kilogram of soil sample (mg/kg).

The petroleum impacted sites used for this research 
were tilled with the aid of shovels to loosen the soil and also enhance aeration. The tilled soil was then mixed, using rakes; this was to further homogenize the soil in order to create favourable condition for plant growth. The use of rake was also intended to obtain a near uniform concentration of petroleum hydrocarbon in the experimental plots. The cultivated/tilled experimental plots were then sub-divided into eight sub-plots (quadrants) or blocks of about $2.1 \mathrm{~m} \times 1.5 \mathrm{~m}$ by means of furrows between the flat ridges. The sub-plots were labelled A - H, based on the number of treatments intended for the study.

The eight sub-plots were subjected to different treatments. Experimental plots labelled "A" were planted with carpet grass (Axonopus compressus) only, without soil amendments. The Plots tagged "B" was treated with nutsedge (Cyperus rotundus) without soil amendments (see Figure 1). Plots labelled "C" were planted with both nutsedge and carpet grass without soil amendment. Plots "D" served as control without any treatment. Plots "E" were treated with carpet grass and soil amendments. Plots "F" were planted with nutsedge and soil amendment. Plots "G" were treated with a mixture of nutsedge, carpet grass and soil amendments, while plots " $\mathbf{H}$ " were treated with only soil amendments. These treatments were applied in such manner so as to find out the effect of each plant species, the effect of both plant species, the effect of soil amendments, and the combined effect of the three treatments on the reduction of petroleum hydrocarbon in the impacted soil, during the research period.

These plants were selected based on certain features thought to enhance phytoremediation. These include the ability of the plant to survive adverse environmental conditions, fibrous root system and high rate of evapotranspiration to enhance phytostabilization. Thus, Cyperus rotundus and Axonopus compressus were selected. The basic features are discussed below: Cyperus rotundus: it is a perennial plant that may reach a height of up to $40 \mathrm{~cm}$. The names "nut grass" and "nut sedge" (shared

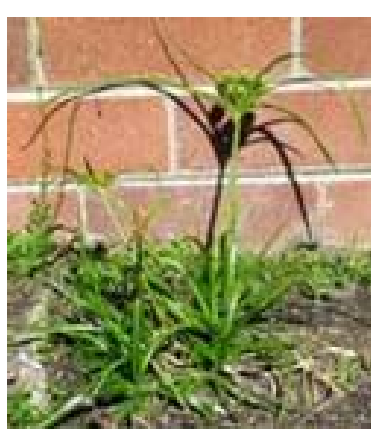

Cyperus sp.

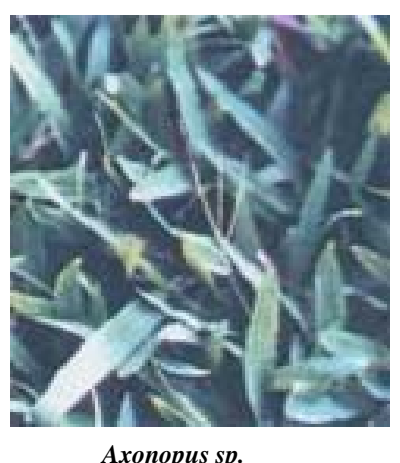

Axonopus sp.
Figure 1. Plant species used in experiment. with the related species Cyperus esculentus) are derived from its tubers, that somewhat resemble nuts, although botanically they have nothing to do with nuts. The root system of a young plant initially forms white, fleshy rhizomes. Some rhizomes grow upward in the soil, and then form a bulb-like structure from which new shoots and roots grow, and from the new roots, new rhizomes grow. Axonopus compressusz is a perennial, coarseleaved, creeping grass. It grows better on low, wet soils than do other grasses. It will grow well in either sun or shade but is less shade tolerant than St. Augustine and Centipede grass which it resembles. These features enhanced the ability of these plants to remove oil from the spill sites.

After land preparation, the plant species for this study (Cyperus rotundus and Axonopus compressus) were transplanted on the respective plots labelled against them. The spacing was $20 \mathrm{~cm} \times 20 \mathrm{~cm}$. This was to ensure proper foliation and fast vegetative ground cover. Both organic and inorganic manures were applied as soil amendments. Soil amendments are organic (Manure) or inorganic (fertilizers) substances added to the soil to improve its fertility and other properties. The potential of mineral fertilizer to improve the productivity of tropical soil has been elaborately investigated. [23] reported that high dose of nitrogen and phosphorus was able to restore the productivity of an eroded alfisol to the original top soil level in southern Nigeria. [13,23] have also shown that adequate irrigation was necessary to compliment the benefits of added organic fertilizers. Similarly, [13] showed that amendment of contaminated soil with urea enhanced the effect of phytoremediation and the decrease of Cadmium concentration in the soil was more significant. The best effect was demonstrated after application of "ispolin": concentrations of $\mathrm{Cd}, \mathrm{Cu}, \mathrm{Pb}$, and $\mathrm{Zn}$ in the rhizosphere decreased $1.2-1.4$ times as compared with those in the initial contaminated soil (the decrease was statistically significant). Green manure was incorporated at the tillage stage to improve the following soil properties: soil moisture, soil aeration, soil nutrients and soil micro-organisms. Inorganic fertilizer, in the form of Urea, was applies a week before transplanting and two weeks after transplanting. Note however, that not all the plots were subjected to this treatment. Only plots E, F, G and $\mathbf{H}$ were treated with soil amendments.

Soil samples were then collected from the petroleum impacted soil in the experimental plots at the surface to a depth of about $12 \mathrm{~cm}$. One random soil sample was collected, with hand-trowel, from each experimental block into beakers, covered with polyethylene bags and secure with elastic rubber band. These soil samples were taken the same day to the laboratory and analysed for TOG at the beginning and repeated at end of the experiment. The 
result obtained was tabulated. Other parameters, such as loss in TOG, and Percentage loss were then derived from the result of the analysis.

The following laboratory equipment/apparatus were used by the researcher for this study: Sartorius analytical balance for weighing of soil samples, beakers $(100 \mathrm{ml})$, conical flasks $(100 \mathrm{ml})$, separating funnels $(500 \mathrm{ml})$, retort stands, volumetric flasks (100 ml), filter papers, washbottles, graduated measuring cylinders $(100 \mathrm{ml})$, cuvette, spatula, $\mathrm{pH}$ meter (mettler Toledo), latex hand-gloves, tetrachloroethylene, hexane, Ultraviolet (Uv) spectrometer and Fourier Transform Infrared (FTIR) spectrometer. Total Oil and Grease (TOG) in the soil samples collected were analysed with Frontier Transmission Infra Red (FTIR) and Ultra Violet (UV) methods.

TOG Analysis by FTIR: Oil impacted soil samples were collected and air-dried. About 1gram of soil was placed in a clean beaker and weighed. The soil was then poured into a separating funnel. $20 \mathrm{ml}$ of the solvent (tetrachloroethylene) was added and allowed to settle in a retort stand. After 5 minutes, the supernatant was filtered into a volumetric flask. The extraction was repeated three times (this is a standard laboratory procedure meant to ensure complete extraction of the oil from the impacted soil sample). The extract was made up to $100 \mathrm{ml}$ with the extraction solvent (tetrachloroethylene). A cuvette was filled with the extraction solvent; this was called "blank". The supernatant extracts from each soil samples were then poured into separate cuvettes. The cuvette with blank was first placed in the FTIR chamber to confirm calibration, after which Infrared analysis was run for each sample extract. The analysis of TOG is based on US Environmental Protection Agency (EPA) Methods 413.2 and 418.1 [17].

TOG Analysis by UV: Soil samples collected before and after the experiment were analysed for Oil content. Before the analysis, the soil samples were air-dried. Five grams (5 g) of each of the soil sample was weighed into a beaker. This was carefully turned into a separating funnel. About $2 \mathrm{~g}$ of Sodium Chloride Salt $(\mathrm{NaCl})$ was added. 50 $\mathrm{ml}$ of Xylene was added carefully. The sample was shaken vigorously by inverting the separating funnel several times. The sample was allowed to settle for about 5 minutes for the partition of the phases to take place. The solvent layer was collected through a funnel containing a filter paper and $10 \mathrm{~g}$ of anhydrous Sodium tetraoxosulphate (vi) $\left(\mathrm{Na}_{2} \mathrm{SO}_{4}\right)$. The absorbance was measured using UV/Visible Spectrophotometer at a wavelength of $636 \mathrm{~nm}$. The "Blank" was also subjected to the same treatment as the sample. The Oil content in the soil samples were then determined using the formula below.

$$
x=\frac{y-c}{M}
$$

where:

$x$ is the concentration of oil and grease in the soil samples (mg/kg);

$y$ is the absorbance of the sample less the absorbance of the blank;

$c$ is the intercept; and $M$ is the slope.

\section{Results and Discussion}

The data collected are presented in Table 1 and discussed below.

This study reveals that plants and their associated micro organisms are capable of reducing the concentration of petroleum in an impacted soil. This was determined through the comparison of petroleum hydrocarbon concentration in oil impacted soil before and after the experiments. A comparison of the oil content expressed in terms of TOG (before) $\mathrm{mg} / \mathrm{kg}$ in the impacted soil before treatment and oil content expressed in terms of TOG (after) $\mathrm{mg} / \mathrm{kg}$ after treatment with different management

Table 1. Concentration of petroleum hydrocarbon in oil impacted soil under different treatments employed in Ekpan.

\begin{tabular}{|c|c|c|c|c|c|c|c|}
\hline & Soil sample & Treatment & $\begin{array}{l}\text { TOG (before) } \\
(\mathrm{mg} / \mathrm{kg})-\mathrm{X}_{1}\end{array}$ & $\begin{array}{l}\text { TOG (after) } \\
(\mathrm{mg} / \mathrm{kg})-\mathrm{X}_{2}\end{array}$ & $\begin{array}{l}\text { Hc loss } \\
(\mathrm{mg} / \mathrm{kg})\end{array}$ & $\%$ HC Loss & Ranked \\
\hline 1 & $\mathrm{~A}_{1}$ & Carpet grass only & 3843.08 & 2031.20 & 1811.88 & 47.13 & 6 \\
\hline 2 & $\mathrm{~B}_{1}$ & Nutsedge only & 3843.54 & 2012.37 & 1831.17 & 47.64 & 5 \\
\hline 3 & $\mathrm{C}_{1}$ & Nutsedge + Carpet grass & 3843.30 & 1810.24 & 2033.06 & 52.90 & 4 \\
\hline 4 & $\mathrm{D}_{1}$ & Control & 3843.51 & 3201.01 & 642.50 & 16.72 & 8 \\
\hline 5 & $\mathrm{E}_{1}$ & Carpet grass + Soil amendments & 3842.59 & 1781.86 & 2060.73 & 53.63 & 3 \\
\hline 6 & $\mathrm{~F}_{1}$ & Nutsedge + Soil amendments & 3844.56 & 1762.50 & 2082.06 & 54.16 & 2 \\
\hline 7 & $\mathrm{G}_{1}$ & Nutsedge + Carpet grass + Amendments & 3843.80 & 1568.71 & 2275.09 & 59.19 & 1 \\
\hline 8 & $\mathrm{H}_{1}$ & Only soil amendments & 3841.53 & 2105.02 & 1736.50 & 45.20 & 7 \\
\hline
\end{tabular}

Source: Field work; 2009. 
techniques clearly reveals that phytoremediation has reduced the concentration of petroleum from the impacted soil (see Table 1). This finding agrees with [21] who reported that phytoremediation can be used to manage soil contaminated with petroleum hydrocarbon.

- $\mathrm{A}_{1}-\mathrm{H}_{1}$ soil samples from plot $\mathbf{A}$ - plot $\mathbf{H}$, in Ekpan experimental plot.

- TOG (bt) Total Oil and Grease before treatment.

- TOG (at) Total Oil and Grease after treatment.

Table 1 revealed that nutsedge (Cyperus sp.) plus carpet grass (Axonopus sp.) plus amendments had about $59 \%$ reduction, indicating the highest rate of $\mathrm{HC}$ reduction of oil impacted soil. Next was Nut sedge plus soil amendments (54\%). Carpet grass plus amendments had a TOG reduction of $53 \%$ and the least TOG reduction was found in the control plot with TOG reduction of approximately $17 \%$. Physical observation of the experimental plots before and after phytoremediation clearly revealed that phytoremediation can greatly improve the quality of oil impacted soil. This fact could be seen in Figures 2(a) and (b).

Figure 2(a) shows the effect of treatment of oil impacted soil with Axonopus compressus (carpet grass). Its effect on the reduction of petroleum hydrocarbon is bench marked against the control plot (plot D). For the experimental plot in Ekpan, a TOG concentration of $3843.08 \mathrm{mg} / \mathrm{kg}$ was observed in plot A before treatment with Axonopus sp. and after three months of planting plot A with Axonopus sp. a TOG concentration of 2031.20 $\mathrm{mg} / \mathrm{kg}$ was observed, indicating $47.13 \%$ loss of hydrocarbon from the impacted soil. Plot $\mathbf{D}$ (control plot) had TOG concentration of $3843.51 \mathrm{mg} / \mathrm{kg}$ before experiment. At the end of three months, the concentration dropped to $3201.01 \mathrm{mg} / \mathrm{kg}$, indicating $16.72 \%$ loss in TOG. The loss in TOG observed in plot $\mathbf{D}$ is due to natural attenuation-the ability of the environment to purify itself [24]. However, there is a difference of $30.41 \%$ in oil loss observed between plot $\mathbf{A}$ and plot $\mathbf{D}$, this difference is due to the effect of Axonopus sp. in plot A (see Table $\mathbf{1}$ and Figure 2). This finding also agrees with the findings of [25] and [26], who both observed that higher petroleum

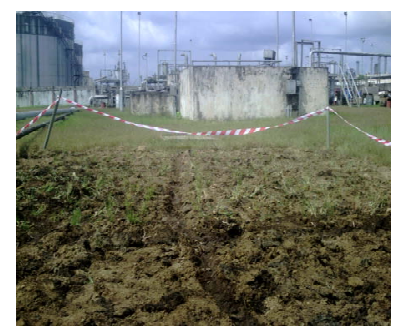

(a)

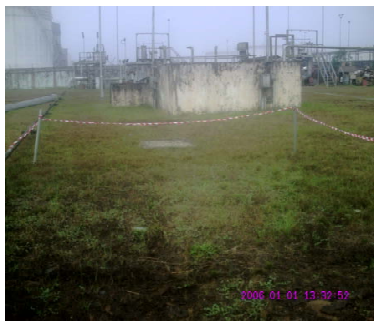

(b)
Figure 2. (a) Oil impacted site in Ekpan before phytoremediation; (b) Oil impacted site in Ekpan after phytoremediation. loss was recorded in planted (vegetated) oil impacted soil than in unplanted (non-vegetated) soil. It was also observed that plot $\mathbf{B}$, planted with Cyperus sp. (nutsedge) recorded greater loss in TOG than plot D which served as control. A difference in hydrocarbon loss of 1188.67 $\mathrm{mg} / \mathrm{kg}$ (representing 47.64\%) between plot $\mathbf{B}$ and plot D can be attributed to the presence of Cyperus sp. in plot $\mathbf{B}$. This corroborated the view of [27] who reported that grasses accelerate the reduction of naphthalene (petroleum hydrocarbon) in soil compared to unplanted soil.

The result from the plot planted with both Cyperus sp. and Axonopus sp. (plot $\mathbf{C}$ ) indicate the synergistic effect of the two plant species which recorded higher TOG loss than either plots $\mathbf{A}$ or $\mathbf{B}$, which were planted with only one plant species. While the plot planted with Cyperus $s p$. and the plot planted with Axonopus sp. recorded 47.13\% and $47.64 \%$ reduction in TOG respectively, the plot planted with both species recorded 52.90\% (see Table 1). This higher reduction in petroleum hydrocarbon shows that there is a synergistic effect. Many studies have shown that mix culture (where it involves micro-organisms) or mix treatment usually result in higher reduction of the contaminant. This finding corroborated with that of [25] who reported that higher hydrocarbon loss was recorded in plot planted with a mixture of grasses. Similarly, [26] reported that a combination of both maize and elephant grass yielded a better alternative in the phytoremediation of a petroleum hydrocarbon contaminated agricultural soil.

This section is set to determine which single plant species was most effective. From the results obtained in table 1, it was observed that Cyperus sp. (nut sedge) planted in plot B was more effective in reducing the level of hydrocarbon in the impacted soil. Cyperus species brought about $47.64 \%$ reduction in hydrocarbon compared with Axonopus species (carpet grass) that reduced the hydrocarbon by $47.13 \%$. This could be ascribed to the fact that Cyperus sp. with a more extensive fibrous root system formed a wider rhizosphere, which is known to be the zone of higher microbial activity, thereby resulting in higher degradation of the petroleum in the soil. This corroborated the findings of [24] who reported that ryegrass with fibrous roots was able to reduce the level of petroleum hydrocarbon in contaminated soil by $97 \%$. According to [28] the extensive fibrous root of the Cyperus $s p$. makes it suitable for phytoremediation [28], and the ability of Axonopus sp. grass to thrive under low fertility makes it suitable for use on oil impacted soil.

Table 2 revealed that the percentage reduction in total hydrocarbon from this study corroborated with all the studies listed, most especially with those of Escalantespinosa et al., 2005 (85\% for Cyperus laxus lam), [29] (50\% for Festuca rubra), [30] (70\% for sedge) and [31] 
Table 2. Bioremediation studies.

\begin{tabular}{|c|c|c|c|}
\hline & Bioremediation methods & Degradation rate & References \\
\hline 1 & Ryegrass + Plant growth rhizobacterial (PGPR) & 3 year, $61.5 \%$ & Gurska et al., 2009 \\
\hline 3 & Creeping red fescue (Festuca rubra) & $\begin{array}{l}50 \% \text { reduction in total petroleum } \\
\text { hydrocarbon after } 4 \text { - } 5 \text { months }\end{array}$ & Philips et al., 2006 \\
\hline 4 & Cyperus laxus lam & $\begin{array}{l}90 \% \text { for inoculated and } 85 \% \text { for } \\
\text { non-inoculated }\end{array}$ & $\begin{array}{l}\text { Escalante-Espinosa et al., } \\
2005\end{array}$ \\
\hline 5 & $\begin{array}{l}\text { Phytoremidiation by tall wheat grass, } \\
\text { Altai wild rye AWR and alfalfa }\end{array}$ & $30 \%-50 \%$ & Philips et al., 2009 \\
\hline 6 & Phytoremidiation with graminaceous plants & $150 \mathrm{~d}: 2.33$ - 3.19 times higher than control & Zhang et al., 2009 \\
\hline 7 & $\begin{array}{l}\text { Phytoremediation with willow (salice exigua), } \\
\text { popliar (populus spp.), eastern gama grass } \\
\text { (tripsacul dactyloides), arrowhead } \\
\text { (sagitaria latifolia), switch grass (panicum virga- } \\
\text { tum), } \\
\text { and sedg (carex stricta) }\end{array}$ & $\begin{array}{l}1 \text { year } 70 \% \text { for sedge, switchgrass, gamagrass, } \\
\text { and } 20 \% \text { for willow, poplar, or no plant }\end{array}$ & Euliss et al., 2008 \\
\hline 8 & $\begin{array}{l}\text { Phytoremediation with cyperus sp., } \\
\text { axonopus sp. and soil amendments }\end{array}$ & $59 \%$ reduction in total hydrocarbon after 3 months & Author's field work, 2009 \\
\hline 9 & Phytoremediation with cyperus sp. & $48 \%$ reduction in total hydrocarbon after 3 months & Author’s field work, 2009 \\
\hline 10 & Phytoremediation. axonopus sp. & $47 \%$ reduction in total hydrocarbon after 3 months & Author’s field work, 2009 \\
\hline 11 & Phytoremediation. cyperus sp.and axonopus sp. & $53 \%$ reduction in total hydrocarbon after 3 months & Author's field work, 2009 \\
\hline
\end{tabular}

Source: Modified after Tang, et al. (2010).

(30\% - 50\% for Altai wild rye AWR and alfalfa). While the combine effect of Axonopus sp. and Cyperus sp. Accounted for $53 \%$ reduction in hydrocarbon in this study, those of tall wheat grass, Altai wild rye AWR and alfalfa studied by [31-33] which accounted 30\% - 50\%. This indicates that that the synergy of Axonopus sp. and Cyperus sp. is 3\% more effective in the reduction of hydrocarbon in soil than those of tall wheat grass, Altai wild rye AWR and alfalfa studied by [31,34] which accounted 30\% - 50\% and the Axonopus sp. and Cyperus sp. accounted for $47.1 \%$ and $47.64 \%$ respectively.

\section{Conclusion}

The study has demonstrated that Cyperus sp. and Axonopus sp. can be used as a phytoremediation technique for the reclamation of oil impacted soils. Their usage is more effective when applied together with organic and inorganic manure. It is therefore recommended that apart from physical clean-up of oil spills sites, Axonopus sp. and Cyperus sp. should be used in phytoremediation to restore the environment back to its natural state.

\section{REFERENCES}

[1] M. K. Bank, H. Mallede and H. Rathbone, "Rehizoshere Microbial Characterization in Petroleum Contaminated Soil," Soil and Sediment Contamination, Vol. 12, No. 3, 2003, pp. 371-385. doi:10.1080/713610978
[2] M. M. Amro, "Treatment Techniques of Oil Contaminated Soil and water Aquifers,” International Conference on Water Resources and Arid Environment, 2004, pp. 1-3. http://hdl.handle.net/123456789/2442

[3] UN Report, "Protecting Ecosystem for People and Planet," United Nations Environmental Programme, 2001, pp. 130147.

[4] A. I. Etang, "The Nigerian State; Oil Exploitation and Community Interest: Issues and Perspectives,” University of Port Harcourt, Harcourt, 1997.

[5] S. I. Efe, "Spatial Variation in Acid and Some Heavy Metal Composition of Rainwater Harvesting in the Oil Producing Region of Nigeria,” Natural Hazard, Vol. 55, No. 2, 2010, pp. 307-319. doi:10.1007/s11069-010-9529-2

[6] C. M. Frick, Farell and J. J. Germida, “Assessment of Phytoremediation as an in-Situ Technique for Cleaning Oil Contaminated Sites,” Phase 1 Final Report, University of Saskatchewan, Saskatoon, 1999.

[7] T. A. Anderson and B. T. Walton, "Comparative Fate of Trichloroethylene in the Root Zone of Plants from Former Solvent Disposal Site," Environmental Toxicology and Chemistry, Vol. 14, 1995, pp. 2041-2047.

[8] S. Trapp, A. S. Ucisik, D. Romano and M. Larsen, "The Role of Plant and Bacteria in Phytoremediation-Kinetic Aspect of Bioremediation of Soils Contaminated with Aromatic Compounds in NATO Science Series IV,” Earth Environmental Science, Vol. 76, 2007, pp. 41-49.

[9] H. L. Yuan, J. S. Yang, B. Z. Wang, L. Li and R. Z. Zhang, "Microorganism Screening for Petroleum Degradation and 
Its Degrading Characteristics," China Environmental Science, Vol. 23, No. 2, 2003, pp. 157-161.

[10] H. S. Jop, P. M. Ndegwa, M. Shoda and C. G. Phae, "Bioremediation of Oil-Contaminated Soil Using Candida Catenulata and Food Waste,” Environmental Pollution, Vol. 156, No. 3, 2008, pp. 891-896. doi:10.1016/j.envpol.2008.05.026

[11] E. Cervantes-Gonzalez, L. I. Rojas-Avelizapa, R. CruzCamarillo, N. G. Rojas-Velizapa and J. Garcia-Mena, "Isolation and Identification by 16S rDNA Partial Sequencing of Hydrocarbon-Chitinolytic Bacteria Involved in Hydrocarbon Removal Process," Progress Environmental Science and Technology, Vol. 1, 2007, pp. 1143-1149.

[12] S. D. Cunningham, J. W. Huang, J. Chen and W. R. Berti, "Abstracts of Papers of the American Chemical Society," American Chemical Society, Vol. 212, 1996, p. 87.

[13] I. Shtangeeva, "Improvement of Phytoremediation Effects with Help of Different Fertilizers," Journal of Soil Science and Plant Nutrition, Vol. 50, No. 6, 2004, pp. 885889.

[14] J. Tang, X. Niu, Q. Sun and R. Wang, "Bioremediation of Petroleum Polluted Soil by Combination of Ryegrass with Effective Microorganisms," Journal of Environmental Technology and Engineering, Vol. 3, No. 2, 2010, pp. 8086.

[15] J. Wang, Z. Z. Zhang, Y. M. Su, W. He, F. He and H. G. Song, "Phytoremediation of Petroleum Polluted Soil," Petroleum Science, Vol. 5, No. 2, 2008, pp. 167-171.

[16] Y. Chen, G. H. Li, X. Zhang, X. X. Lu and L. Zhang, "Effect of Petroleum Biodegradation and Rhizosphere Micro Eco-System in Phytoremediation of the Polluted Soil in Oilfield,” Science and Technology, Vol. 45, No. 6, 2005, pp. 784-787.

[17] R. Sandra, "Oil and Grease Measurement for Water and Soil Samples,” The Global Directory for Environmental Technology, 2005. www.eco-web.com

[18] R. Ferrera-Cerrato, A. Alarcon, M. R. Mendoza-Lopez, W. Sangabriel, D. Trejo-Aguilar, J. S. Cruz-Sanchez, C. Lopez and J. Ortiz, "Delgadillo-Martinez. Phytoremediation of a Fuel Oil Polluted Soil with Phaseolus Coccineus Using Organic or Inorganic Fertilization,” Agrociencia, Vol. 41, No. 8, 2007, pp. 817-826.

[19] J. E. Kaimi, T. Mukaidani and M. Tamak, "Screening of Twelve Plant Species for Phytoremediation of Petroleum Hydrocarbon Contaminated Soil," Plant Production Science, Vol. 10, No. 2, 2007, pp. 211-218. doi:10.1626/pps.10.211

[20] K. V. Nedunuri, R. S. Govindaraju, M. K. Banks, P. Schwab and A. Z. Chens, "Evaluation of Phytoremediation for Field Scale Degradation of Total Petroleum Hydrocarbons," Journal of Environmental Engineering, Vol. 26, No. 6, 2000, pp. 483-490. doi:10.1061/(ASCE)0733-9372(2000)126:6(483)

[21] S. McClutchen and J. Schnoor, "Phytoremediation Transformation and Control of Contaminants," John Wiley and Sons. Inc., Hoboken, 2003.
[22] R. Shirdam, A. D. Zand, G. N. Bidhendi and N. Mehrdadi, "Phytoremediation of Hydrocarbon-Contaminated Soils with Emphasis on the Effect of Petroleum Hydrocarbon on the Growth of Plant Species," Phytoprotection, Vol. 89, No. 1, 2008, pp. 21-29.

[23] B. A. Badejo, "Strategies and Tactics of Sustainable Agriculture in the Tropics," College Press Publication, Nigeria, 2001, pp. 16-17.

[24] T. Gunther, U. Dornberger and W. Fritsche, "Effects of Ryegrass on Biodegradation of Hydrocarbons in Soil," Chemosphere, Vol. 33, No. 2, 1996, pp. 203-215. doi:10.1016/0045-6535(96)00164-6

[25] W. Aprill and R. C. Sims, "Evaluation of the Use of Prairie Grasses for Stimulating Polycyclic Aromatic Hydrocarbon Treatment in Soil,” Chemosphere, Vol. 20, No. 12, 1990, pp. 253-265.

[26] J. M. Ayotamuno, R. B. Kogbara and P. N. Egwuenum, "Comparison of Corn and Elephant Grass in the Phytoremediation of a Petroleum-Hydrocarbon-Contaminated Agricultural Soil in Port Harcourt, Nigeria,” International Journal of Food, Agriculture and Environment, Vol. 4, 2006, pp. 218-222.

[27] X. Qiu, T. W. Leland, S. I. Shah, D. L. Sorensen and E. W. Kendall, "Chapter 14: Field Study: Grass Remediation for Clay Soil Contaminated with Polycyclic Aromatic Hydrocarbon,” In: E. L. Kruger, T. A. Anderson and J. R. Coats, Eds., Phytoremediation of Soil and Water Contaminants, American Chemical Society, Washington DC, 1997, pp. 186-199. doi:10.1021/bk-1997-0664.ch014

[28] C. Archer, “Cyperaceae,” National Herbarium, Pretoria, 2005.

[29] L. A. Phillips, C. W. Greer and J. J. Germida, "Culture-Based and Culture-Independent Assessment of the Impact of Mixed and Single Plant Treatments on Rhizosphere Microbial Communities in Hydrocarbon Contaminated Flare-Pit Soil,” Soil Biology \& Biochemistry, Vol. 38, No. 9, 2006, pp. 2823-2833. doi:10.1016/j.soilbio.2006.04.038

[30] K. Euliss, C. Ho, A. P. Schwah, S. Rock and M. K. Banks, "Greenhouse and Field Assessment of Phytoremediation for Petroleum Contaminants in a Riparian Zone,” Bioresource Techology, Vol. 99, No. 6, 2008, pp. 1961-1971.

[31] L. A. Phillips, W. G. Charles, R. E. Farrell and J. J. Germida, "Field-Scale Assessment of Weathered Hydrocarbon Degradation by Mixed and Single Plant Treatments," Applied Soil Ecology, Vol. 42, No. 1, 2009, pp. 9-17. doi:10.1016/j.apsoil.2009.01.002

[32] E. Escalante-Espinosa, M. E. Gallegos-Martinez, E. F. Torres and M. Gutierrez-Rojas, "Improvement of the Hydrocarbon Phytoremediation Rate by Cyperus laxus lam. Inoculated with a Microbial Consortium in a Model System,” Chemosphere, Vol. 59, No. 3, 2005, pp. 405-413. doi:10.1016/i.chemosphere.2004.10.034

[33] J. Gurska, W. X. Wang, K. E. Gerhardt, A. M. Khalid, D. M. Isherwood, X. D. Huang, B. R. Glick and B. M. Greenberg, "Three Year Field Test of a Plant Growth Promoting Rhizobacteria Enhanced Phytoremediation Sys- 
tem at a Land Farm for Treatment of Hydrocarbon Waste," Environmental Science Technology, Vol. 43, No. 12, 2009, pp. 4472-4479. doi:10.1021/es801540h

[34] L. A. Nwaogu, G. O. C. Onyeze and R. Nwabueze, "Deg- radation of Diesel Oil in a Polluted Soil Using Bacillus subtilis," African Journal of Biotechnology, Vol. 7, No. 12, 2008, pp. 1939-1943. 